\title{
Local Wisdom Based Da'wah in the Oral Tradition of the Jambi Malay Seloko Adat
}

\author{
Sihabudin Noor* \\ Faculty of Da'wah and Communication, UIN Syarif Hidayatullah Jakarta \\ *Email: sibabudin.noon@uinjk.t.ac.id
}

\begin{abstract}
On its arrival in Jambi, Islam had interacted with the indigenous culture. Through pacifique penetration, Islam influenced local society and socio-cultural institutions. Islam used the traditional poem of seloka which is a form of the Malay spoken literature as a medium to spread out the Islamic values and thoughts. Islam even became the main source in establishing the Jambi's local culture and wisdom. The study explains da'wah in local wisdom of traditional poem of seloka (seloko, Jambinese) Jambi Malay. Using qualitative method by reading and learning the main research sources of descriptive data which were manuscripts of traditional poem of seloka. Interview with resource persons who were competent on content and value of the poems were also conducted to enhanche the interpretation on data. The conclusion of the study finds that the da'wah movement based on local wisdom brought about tightly bound relation between Islam and Jambi Malay Culture; Islamic value were modified into traditional law that commonly use seloka. The reality shows there is harmony between the local culture and the Quran and Sunnah.
\end{abstract}

Keywords: Islam; culture; traditional poem of seloka; local wisdom; da'wah

\begin{abstract}
ABSTRAK
Islam mempengarubi masyarakat dan institusi sosial-budaya setempat. Dengan memanfaatkan seloko adat yang merupakan salah satu bentuk sastera lisan Melayu, bahasa sastera ini menjadi alat penyemai nilai dan ajaran Islam, sehingga pada akhirnya agama ini menjadi sumber utama bagi pembentukan adat dan kearifan lokal. Artikel ini menjelaskan dakwah dalam kearifan lokal seloko adat Melayu Jambi. Islam sejak awal kedatangannya telah berinteraksi dengan budaya setempat. Lewat penetrasi damai (pacifique penetration), Menggunakan metode kualitatif, penelitian ini berupaya mempelajari dan memahami naskah seloko adat dan kaitannya dengan kearifan lokal dan dakwah Islam. Wawancara ke beberapa tokoh penting dilakukan sebagai bagian dari pengayaan data untuk memahami lebih lanjut mengenai isi dan nilai seloko. Kajian ini menyimpulkan bahwa akibat adanya gerakan dakwah yang berkearifan lokal dalam budaya Melayu Jambi terdapat bubungan yang erat antara Islam dan budaya masyarakat melayu Jambi; seperti adanya modifikasi nilai-nilai Islam ke dalam bukum adat yang umumnya menggunakan bahasa seloko. Realitas itu menunjukan adanya harmoni antara budaya lokal dengan Alquran dan Sunnab Rasul.
\end{abstract}

Kata kunci : Islam; budaya; seloko adat melayu; kearifan lokal; dakwah. 


\section{INTRODUCTION}

In studying the da'wah with the local wisdom of the Jambi Malay seloko adat, it is essential to know how the relation between Islam and Jambi Malay culture occurred; Namely from what and how the values and teachings of Islam affect the culture of one of the Malay tribes. Islam, which since its arrival in the 7th century AD to the East coast of the island of Sumatra (Jambi) is a foreign element (culture) came to an inhabited area. Through pacifique penetration, the religion was slowly but steadily entering and was voluntarily accepted into local communities and cultural institutions. Through the ingenuity of the preachers in ingraining the values and teachings of Islam, they made use of seloko adat which is one of the elements of oral literary culture that is quite influential in the Jambi Malay community.

The peaceful relation between Islam and the local cultures, manifested in the local wisdom based da'wah, occurred without losing the original nature and character of the cultures. The blending of local values and Islam eventually become an inseparable part and also become the culture of the Jambi Malay community. Islam even became the source of local wisdom. This study is made to examine on what is and how local wisdom based da'wah of Seloko adat of the Jambi Malay is conducted.

Local wisdom is conceptually originated from local/traditional knowledge and management (Mitchell, et.al., 2000; Mustafid, 2009). It is the compilation of numerous knowledges or way of thinking based on human culture in an interrelated period of time and the result of long period of observation. Local/traditional wisdom is the knowledge of culture of specific groups of society consisting of a number of knowledges/cultures on how to manage and utilize nature in a sustainable way.

Local wisdoms consist of the knowledge of the society related with the structure and the function of the environment and reaction of the nature on human actions (Arafah, 2002). Thus, local wisdom encompasses numerous forms of knowledges, beliefs, understanding/insights and habits/ethics which guide humans in their ecological community (Keraf, 2006). Besides that, local wisdom can also be interpreted as a form of human intelligence in managing natural environment by maintaining ecological balance of nature that has been carried out since a long time ago and has been tested in various disasters caused by nature or human activities. Humans were then inspired to develop wisdom towards nature in the form of knowledges or ideas/custom norms, cultural values activities and tools in managing nature and the environment (Wahono, 2005).

Local wisdom can also be understood as human efforts carried out in utilizing cognitive ability in taking action and react on something, an object or events occurring in space and time. Therefore, etymologically, wisdom is understood as the human ability in utilizing reasoning in taking actions or reacting 
towards the result of evaluation on something, an object or events. The term wisdom is often interpreted as the knowledge and application of a culture acquired over time. So specifically, local context refers to limited interactions of value system; space of interaction is designed in the form of involvement of inter human interactions, or humans with the environment. Humans can then directly arrange face to face relation with their environments which in turn create values that became the foundation for their relationships or a guidance for their behaviors (Ridwan, 2007, p.2).

Local wisdom was then manifested in cultural elements encompassing religious system; social and social organization system; knowledge system; language; art; livelihood system; technology and equipment system (Koentjaraningrat, 1990:2). Local wisdom manifests in three aspects including (1) ideas, values, norms, regulations; (2) behavior patterns, complex activities; and (3) artifacts, culture, materials, cultural objects (Koentjaraningrat, 1990, p.5).

In certain community religious systems (for example $\mathrm{x}$ ), local wisdom is manifested in the form of ideas, norms, and regulations that affects patterns of community behavior. The result is the form of objects that originate from their culture. Local wisdom can also be manifested in the form of values, norms, beliefs, and special rules. The wide range of results ensue a variety of local wisdom functions. The functions are as a means for the conservation and preservation of natural resources, human resource development; cultural and scientific development; as advice, beliefs, literature and taboos (Sartini, 2004).

The wealth of local wisdom can be observed as in the cultural display of the archipelago, which according to Koentjaraningrat (1990), starts from the culture in the western islands of Sumatra, the north coast communities of Irian Jaya (Papua), Batak, Bugis-Makasar, Bali, Sunda, Java and even Chinese (Koentjaraningrat, 1980). The form includes social systems, kinship, religion, language, art and others.

As an explicit knowledge, local wisdom materialized from a long period of time that simultaneously evolved along with the community and the environment. This process becomes local wisdom, and becomes the energy of the collective knowledge system (Tiezzi et al., 2003.). Local wisdom eventually dynamizes people's lives with full of courtesy. It becomes generally accepted values that are believed to be true, and serves as a guide for behavior. Local wisdom determines the dignity of a person in the community because it contains elements of intelligence, and creativity from the local knowledge of the elites and their communities, and ultimately determines the success of the development of civilization (Ridwan, 2007, p.3).

The existence of religious reality in a region is definitely influenced by culture. Culture of the archipelago (Indonesia) with its uniqueness such as being open to migrants, keen on mutual cooperation, tolerant, having a high sense of solidarity is very likely to influence the behavior of socio-religious patterns that 
develop. Considering the importance of local wisdom, the propagators of Islam (dai) try to understand, explore and develop local wisdom. This is because as local ideas, they are wise, full of wisdom, of good value, embedded and followed by members of the community. Therefore it can be used as a means to convey the message of preaching.

The Dais understand the importance of local wisdom because the truth of their knowledge has been traditionalized in a region; it is formed from the cultural superiority of its people who are able to deal with the influence of foreign cultures (Rosidi, 2011, p.29). According to Teezzi, Marchettini and Rosini, such are manifested in the form of tradition or religion (Radmilla, 2011).

Local wisdom can be found in various forms of cultural expressions such as in the three categories of Koentjaraningrat cultural forms, through the form of ideas, values, norms, and regulations; behavior patterns, and complex activities; artifacts, culture, material, and cultural products (Koentjaraningrat, 1990, p.5). The form is recorded in singing, proverbs, sasanti, advice, motto, and ancient books that are inherent in everyday behavior. In addition, local wisdom is reflected in the habits of life of the people in which there are values that prevails and become the basis of daily life.

This sedimentation process requires a very long time, from one generation to the next. Teezzi, Marchettini, and Rosini say that the emergence of local wisdom in the society is the result of a trial and error process of various kinds of empirical or non-empirical knowledge or that is aesthetic or intuitive (Tiezzi et al., 2003). Local wisdom describes more to a specific phenomenon that will usually be a characteristic of the group's community for example alon-alon asal klakon (Central Javanese society), rawe-rawe rantas malang putung (East Java society), ikblas kiai-ne manfaat ilmu-ne, patuh guru-ne barokah urip-e (pesantren community), and so on (Ridwan, 2007).

Every environment certainly has certain settings regarding ideal relations, and these settings actually become the spirit in community behavior (Wirawan, 1992). According to the theory of human ecology there is a reciprocal relationship between the environment and behavior; The environment can influence behavior, and behavior can also affect the environment. The emphasis of this theory is existence of settings in an environment composed of structures that influence each other, and within these structures there are certain settings as well (Ridwan, 2007).

Local wisdom can in due course defined as a wealth of local cultures containing a living policy; way of life that accommodates policy (wisdom) and wisdom of life. As in the archipelago which later became Indonesia, local wisdoms were not only implemented locally to certain cultures or ethnicities. They then become cross-cultural or cross-ethnic and forms national cultural values such as those found in almost every local culture that teaches the wisdom of mutual cooperation, tolerance, work ethic, deliberation and so on. Ethics and 
moral values are then taught from generation to generation, and passed down from generation to generation through oral literature (among others in the form of proverbs and proverbs, folklore), and manuscripts. Local wisdom then becomes knowledge that was originally developed by the ancestors in anticipating the environment around them, and is passed on from generation to generation through stories, legends, songs, rituals, and also rules or local laws (Suyono Suyatno, tt). Local wisdom can be understood as local ideas that are wise, full of wisdom, having good value, implanted and obeyed by members of the community. In the discipline of anthropology, there is a term local genius. This term was first introduced by Quaritch Wales. Anthropologists discuss at length the notion of local genius (Ayatroehadi, 1986). Haryati Soebadio said that local genius is also a cultural identity (national cultural identity/personality) which enable the nation to absorb and process foreign cultures in line with their own characters and abilities (Ayatroehadi, 1986).

Moendardjito said that the element of regional culture has the potential to be a local genius because its ability to survive until now has been proven. The characteristics of local wisdom include: First, being able to withstand external culture; Second, having the ability to accommodate elements of external culture; Third, has the ability to integrate elements of external culture into native culture; Fourth, has the ability to control; Fifth, able to provide direction for cultural development. Local wisdom is a national cultural identity/personality that causes the nation to be able to absorb and process foreign cultures according to their own character and abilities (Ayatroehadi, 1986). Local wisdom is human intelligence possessed by certain ethnic groups that is obtained through community experience through a long period of time, throughout the existence of these communities and not necessarily experienced by other communities (Rahyono, 2009).

Seloko adat is a traditional oral expression/statement that has influenced the culture of the Jambi society. Seloko as oral tradition is passed down in the form of speech, which has a figurative meaning and understanding. It contains messages, advices that have ethical and moral values. The use of this expression in society becomes a daily habit intended to strengthen the values and norms that prevails in society. So that in practice it can be traced to the role of adat (custom) in fostering communities which is sometimes accompanied by sanctions or laws should violations occur.

Seloko adat adat was shaped as a codification of the cultural values of its people. The expression reflects the way of life in the form of religious, ethical and moral values. So the seloko phrase includes the rules of social institutions and behaviors that are considered correct. As reflected in the expression "Adat bersendi Syarak, Syarak bersendi Kitabullab". ("Adat with Syarak, Syarak with Islamic Book"). (Adat refers to Islamic teaching and law, while Islamic teachings and law are originated from the Qur'an) (Rahima, 2013). 
Seloko adat is directly delivered by the community to communicate on a daily basis. It is also used in official activities. But in terms of cultural roots of the Jambi Malay tribe which is very strong, it turns out this tradition has been carried out since the establishment of the Jambi Malay kingdom, and was made as a custom from generation to generation as a means of association and governance. Through seloko oral literature, messages and daily communication are conveyed (Syam, 2003, p.6). The use of seloko is still maintained by the people even though there have been cultural shifts due to foreign cultural influences (Rahima, 2013).

The study of da'wah in the local wisdom of the Seloko adat of Jambi Malay is inseparable from how the relationship between Islam and Jambi Malay culture occurred; Namely from what and how the values and teachings of Islam affect the culture of one of the Malay tribes. Islam, which since its arrival around the 7th century AD to the East coast of the island of Sumatra (Jambi) is a foreign element (culture), and arrived on an inhabited area. Through pacifique penetration, the religion slowly but steadily entered and was voluntarily accepted into local communities and cultural institutions. Through the ingenuity of the preachers in ingraining the values and teachings of Islam, they make use of seloko adat, one of the elements of oral literary culture, which is quite influential in the Jambi Malay community.

The peaceful relationship between Islam and the local culture manifested in the propagation with local wisdom took place without having to eliminate the nature and elements of the original culture. Islamic values and teachings eventually become an inseparable part of the culture of the Jambi Malay community. Islam has even become a source of local wisdom. This paper aims to examine what and how the preaching based on local wisdom of seloko adat of Jambi Malay was carried out.

This research is different from those who study seloko adat such as one by M. Ed Al Munir and Muslim H. Ja'far who talked about "Ethics of Leadership in Seloko Malays Indigenous Jambi" (Al Munir, 2013). This study addresses at least three main questions about what constitutes ethical leadership, how leadership in Malay culture in Jambi works and how ethical leadership based on Seloko Jambi habits is implemented.

Another research on seloko adat was carried out by Nurhasanah who examined the "Symbolic Expression of the Indigenous Seloko Jambi" (Nurhasanah, 2013) Nurhasanah stated that the Jambi seloko adat was the worldview of the people about all aspects of human life. Seloko studies about the person, the world, and God. In her study, Nurhasanah concluded that the effort to formulate or embody life outlook through adat seloko expressions was a symbolic activity of the Jambi people, and something that is humane. Therefore Seloko Adat Jambi was actually the effort of the Jambi people in compiling their cultural reality in the form of oral statement symbols. 
While Yudi Armansyah studied adat seloko related to "Contribution of Jambi seloko adat in Strengthening Local Democracy" (Armasyah, 2017). This study is to see whether the values in Seloko Adat Jambi can work together in developing democracy. Democracy itself comes from the tradition of Ancient Greece and was developed by the tradition of Western thought. While the oral tradition of seloko Jambi was developed within the Malay cultural tradition and is heavily influenced by Islamic teachings that highly uphold moral and ethical values (morals). The question is whether the Jambi Malay seloko adat is compatible with the concept of democracy. Yudi concluded that seloko adat Jambi has universal values so that it can work together in strengthening democracy. Some universal values include the principle of decision making in government; the principle of justice; principle of equality; leader wisdom; the principle of deliberation to reach consensus; and management and governance.

From all the studies on seloko adat, the study of "Da'wah Islam in the Jambi Seloko Oral Tradition" is the first to be conducted. This is important because the development of seloko adat which is full of values of da'wah and propaganda that supports the virtue of adat seloko values eased understanding in the development of Islam in the Jambi Malay community.

Based on the history of the spread of Islam in Jambi, the use of seloko adat as an Islamic propaganda media is not mentioned. As seen in the research conducted by Benny Agusti Putra on "Islamization in the Jambi Malay World", Benny emphasized more on the pattern of the spread of Islam in Jambi which he said were three. First, related to foreign relations between Jambi and other countries through trade routes. Second, the spread of Islam in Jambi was related to the influence of Sufism which is also common in Indonesia. Third, the involvement of local authorities in the process of islamization (Putra, 2018, p.48). While Benny sees the spread of Islam in Jambi was conducted using two patterns, first, the pattern of assimilation when Sufis pay attention to mahayana worship activities. Second, the pattern of accommodation in the form of marriage and trade. In this context Benny did not examine the Islamic propagation approach (da'wah) from the aspect of local culture.

This study is to know local wisdom based da'wah in the oral tradition of the jambi malay seloko adat. Using qualitative method this study was conducted by by reading and learning the main research sources of descriptive data which were manuscripts of traditional poem of seloka. Interview with resource persons who were competent on content and value of the poems were also conducted to enhanche the interpretation on data.

\section{RESULT AND DISCUSSION}


In the daily life of the Jambi community, the use of seloko includes: (1) seloko adat of Jambi in customary law; (2) seloko adat Jambi in the Jambi indigenous marriage; seloko adat Jambi about leadership; (4) Seloko adat Jambi about bad things; (5) seloko adat Jambi in daily life or community life; (6) Seloko adat Jambi on self-obligations; (7) seloko adat Jambi in family life.

As an old literary form, seloko was created, disseminated, and passed down through generations by way of oral traditions in daily life. Seloko has core teachings on cultural and moral values; It contains the advice and views of mamak ninik, tuo-tuo tengganai, cedekia, and ulama. Thus, seloko in daily life becomes the norm, philosophy, basis for thinking, and reinforcing thoughts and feelings. In addition, it is also a media for socialization that has aesthetic value of language so that it can create a strong sense of unity and respect among members of the community (Gafar, 2012, p.43).

The formal tradition of using seloko is generally only carried out on ceremonial activities, such as in traditional marriage ceremonies, welcoming guests/officials, leadership changes and others. The habit of using seloko in daily life among the younger generation began to be abandoned due to the dominance of global culture. Therefore, the Customary Councils at various levels in Jambi Province are trying to preserve it by inviting the younger generation to love Seoloko because it has a positive impact on character building as well as an effort to maintain local wisdom in the seloko cultural tradition.

The seloko adat Jambi belongs to the Malay poetry genre which, according to Harun Mat Piah (Noor, 2016), consists of rhymes, poetry, nadzam, gurindam, seloka (seloko), puzzles, concocted proverbs, taromba, talibun, rhythmic prose/poetry lyrics, spells and zikir. It contains words/sentences that are rich in meaning. Seloko which resembles rhymes and poetry becomes a learning medium for the community because it contains advice, points out teaching, advice, syndicate, laws and provisions. As in traditional expressions in each genre of Malay poetry, it contains subject to teaching as a tool/medium for controlling social systems and the personal formation of its people. It is generally carried out through oral transmission in the form of utterance, maintenance, development, and inheritance of values in traditional expressions carried out between generations to the next generation. As a traditional agreement in the form of poetry, seloko eventually became one of the tools/media for the inheritance of noble values between generations of the Jambi Malay ethnic group.

As a genre of Malay poetry, seloko displays the representation of the Jambi Malay community in which it is filled with cultural values. As a form of oral literature, the transmission is delivered in a direct form from the speaker to the recipient. As a cultural product, seloko was born from the culture and environment that are developed in its community. Through the process of observation of what happened in the social community and an occurrence that was considered special as an externalizing situation, the value of the occurrence 
that ensued was then objectified and became a product of thought about an occurrence. From this process, it is then internalized through the seloko media to the recipient and the rules are shared as a cultural asset.

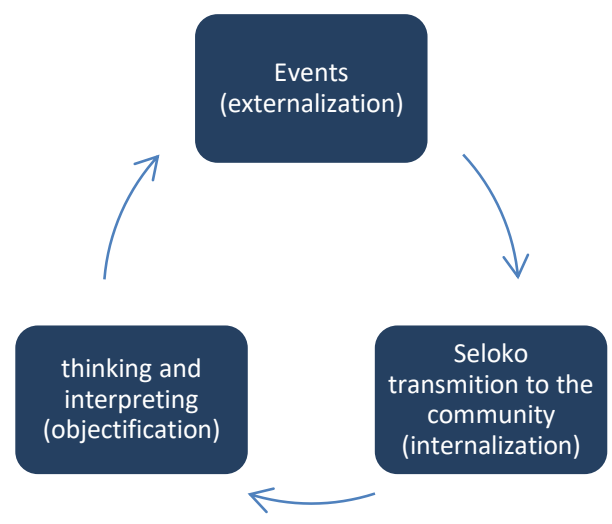

\section{Picture 1: The process of how seloko came about}

As showed in Picture 1, one of the reasons Seloko came about was as a response to the natural environment and every important event that occurred in the social relations system of the community. As illustrated by the the theories of Peter L. Berger and Thomas Luckman on "The Social Construction of Reality" (Berger, 1991), it can be shown that seloko is a linguistic expression in the poetry tradition especially Jambi Malay which contains expressions/utterances. Containing more symbolic expressions, seloko becomes part of the linguistic cultural expression that is born from innovation, creativity, value crystallization, new inventions and discoveries, and adoption of expressions/utterances from other cultures. Thus, in practice seloko is dynamic because it was born from the response of the community to the development of natural and local culture and new habits that come from other cultures. Seloko as a type of poetry which contains teachings / innuendos, as in the form of Malay poetry, contains an A A A A array consisting of sampiran and content. The first two arrays contain sampiran and the second two arrays both contain contents (Noor, 2016). Some examples are as follows:

\section{Apabila berjalan memakai tongkat,}

When walking using stick

takean terasa lelah dan penat

it won't feel bad and tired

Apabila iman sudah melekat, 
when faith is attached

takean susah dunia akbirat

life on earth and Hereafter won't be difficult

Apabila halaman sudah disapu,

Once the garden is swept

tidak ada sampah dan debu

There is no garbage and dust

Apabila iman sudab menyatu,

When faith is united

tentulab bilang bimbang dan ragu

Surely worries and doubt would disappear

Ulat bulu di batang pisang,

Feather worms on a banana stem

kena bulunya terasa miang

It hurts when in contact with the fur

Nasehat guru dikenang-kenang,

the teacher's advice is remembered

supaya hidup tiada terbuang

to make life not wasted

Mengail di tanjung menjala di pantai

To fish in the cape, to net fishing in the beach

bila mendapat makan beramai

Once caught a feast is bold

Keadilan dijunjung kebenaran dipakai

Justice is upheld, truth is implemented

Dunia akhirat aman dan damai

Life on earth and hereafter is peaceful

In sampiran, AA content is as follow:

Tekilak ikan di aek

Tentu jantan betinonyo

Kendak balam padi rebah

Syara berbubul mati

Adat berbubul sentak

Adat bersendi syara

Syara bersendi Kitabullah 
Kalau tak ada berada

Masakan tempua besarang rendah

Begoyang dahan keno angin

Bergerak kincir keno aek

Bekato merendah rendah

Mandi di bawab-bawah

Bekato dulu sepatah

Bejalan dulu selangkah

Rajo alim rajo disembah

Rajo zalim rajo disanggah

Menyanggah rajo dengan undang

Menyanggah alim dengan kitab

Idak becupak begantang dewek

Seloko also consists two paradoxical and causal conditions:

Lamo idup banyak diraso

Jaub bejalan banyak dilibat

Lamo duduk letih teraso

Lamo bediri terasa penat

Besides that, seloko can also be a balance among sampiran and content:

Pisang emas bawa belayar

Masak sebiji di dalam peti

Hutang emas dapat dibayar

Hutang budi dibawa mati

Tak usah kami diberi kain

Dipakai kain dia luntur

Tak usah kami diberi nasi

Dimakan nasi dia habis

Berilab Kami hati yang suci

Muka jernih budi baike terbawa mati

Seloko is a part of Malay oral literature and a form of expression which includes, among others, proverbs, petitih, seloko, advice, and class. Seloko itself has the following characteristics (Noor, 2016, p.1) Seloko is usually distributed on certain occasions such as in traditional ceremonies (marriage, receiving guests, etc.); (2) As an oral literary, seloko is conveyed through word of mouth culture; (3) There are often different variations due to the copying and reporting process 
in different time periods and places; (4) Seloko is usually anonymous because it was born and appeared in the midst of the community and belongs to the community; (5) Seloko in its meaning is usually full of educational values, teaching and entertainment; (6) In practice, seloko does not obey the rules of formal logic because it is sometimes a spontaneous expression from the speaker.

\section{Islam Moderation: Da'wah Based on Local Wisdom in the Oral Tradition of Seloko Adat Jambi Malay}

Islamic da'wah in the archipelago is carried out peacefully (penetration pacifique). Through local culture, values and teachings of Islam are inculcated (cultural acculturation). This method is a method commonly practiced by advocates since long time ago (Kuntowijoyo, 1993; Budiono, 2003; Masroer, 2004).

This peaceful Islamization gave birth to a moderate model of local Islam in the archipelago; All adherents of Islam refer to the same sources; the Qur'an and Sunnah, but in spreading this religion it is done through a local wisdom approach. This local Islam then grew and developed along with the growth development of the community. This approach pattern gave birth to various unique cultural phenomena in each region in the archipelago. With its local characteristics, Islam was present in the midst of local culture, representing Islamic understanding and appreciation of the diversity of ethnic groups in the archipelago (Gibb, 1962; Yatim, 2007).

This characteristic of the locality of Islam did not mean that the Nusantara Islamic community abandoned the continuity of its religious teachings which originated from the Qur'an and Sunnah, and Islamic worship in general. The difference is only in religious expressions. In the course of its history, Islam in the archipelago has helped its adherents understand "reality". Islam in turn manifests itself in patterns of worldview (weltanschanung) in various social and cultural institutions, and influences its surroundings (Azra, 1996, p.i-ii).

Islam which becomes the worldview of its adherents in the archipelago is related to the socio-cultural phenomena around it. In the end, in the relation between the two there exists a relationship of mutual influences; in socio-cultural reality, Islam has a role as a determining subject for the dynamics of the historical development of society. On the other hand, the religion is also subject to pressure from other socio-cultural factors. The ability of Islam in social struggle ultimately depends on the ability and strength of Islam developed by its adherents (Azra, 1996, p.i-ii; Noor, 1997).

Islam and the Jambi Malay ethnic group are inseparable. Islam for the Jambi Malay community has become the identity of life as reflected in the socio-cultural routine of the community (Ulum, 2013). Consequently, seloko adat which is a portrayal of Jambi Malay cultural values is essentially derived from Islamic values (Nurhasanah, 2013)

Islam has entered the Malay realm for more than a thousand years, since the 
first century of the Islamic calendar (1 Hijrah/7 AD). The initial spread of this religion went through multi processes (Abdullah, 2006). Islam brought by its preachers since the 7 th century Sriwijaya kingdom then came into contact with local social and cultural facts in which the system of teachings and values of other religions had arrived earlier (Muzakir, 2010; Aliyas, 2013 ; Putra, 2018).

As trading became more widespread in the cities along the East coast of Sumatra, Cape Malaya and in other islands in the archipelago, the intensity of Islamic relations and local culture also intensified. As their relations on the east coast of the island of Sumatra later found momentum when the sultanate of Jambi emerged. The preachers of Islam then use this relationship by utilizing local culture as a medium for preaching. Slowly but steadily, Islam influences the social, economic, cultural and political nature of Jambi Malay culture. Its noble values even enter the midst of the vortex of culture and civilization. Islam later became patterns of worldview (weltanchauung) institutions and customs. This can be seen as a description in the traditional seloko which includes proverbs, advice, petitihs, and rhymes that are sung at traditional ceremonies (Rahima, 2013; Nurhasanah, 2013).

In the end the values of Islam that entered through the oral literary rules influence the formation of social institutions, and the daily life behavior of the Jambi Malay community (Nurhasanah, 2013), as the phrase:

\section{Adat bersendi syarak, syarak bersendi Kitabullah \\ Syarak mengato, adat memakai \\ Sah kato syara, sab kato adat \\ Syara berbubul mati, adat berbubul sentak.}

The meaning of seloko "adat bersarak syarak, syarak berserah Kitabullah" implies that adat is core in Islamic teachings and laws, and the teachings and laws are originated from the Qur'an. While the notion "Syara mengato, adat memakai, sah kato syarak, sab kato. Adat Syarak berbubul mati (abadi), adat berbubul sentak (sementara)" implies that what has been affirmed by the values and laws of Islam the custom follows it. Islamic values and law are eternal, while adat is temporary/relative (Nurhasanah, 2013). So that in the days of the Jambi Sultanate which was established in the 16th century, the first basis of its constitution was the "Al-Quran and the Hadith of the Prophet" which was given an expression with traditional seloko: "Titian teras bertanggo batu, cermin nan tidak kabur, lantak nan tidak goyah, nan tidak lapuk karena hujan dan lekang keno panas serta kato seiyo" (Lembaga Adat Propinsi Jambi, 1993; Interview with Junaidi T. Noor, 2015).

The life of the Jambi Malay community continues to influenced by Islamic values through the existence of Adat originating from Islamic Sharia, and sharak originating from the Qur'an and Sunnah: "'Titian teras bertanggo batu (stone-laden terraces) (Lembaga Adat Propinsi Jambi, 1993). The meaning of this expression is 
that the terraces are custom, the stone stairs are the Qur'an and the Sunnah. The source of Islamic authority then becomes the customary paradigm and behavior carried out by the supporting community as a form of devotion to Allah the Creator (Ulum, 2013).

Islamic preachers intelligently utilize and take over the values and meanings contained in seloko adat as a means of spreading the values and teachings of Islam. While the seloko which has been Islamized then becomes a source of civilization, culture and forming the social reality of its people. So that Islam which has become a culture has become part of local wisdom, its values and teachings animate and color the existence of customary law, marriage, leadership, prohibitions, community, self-obligation, and family life (Rahima, 2013; Wennyta, 2015).

The relation between Islam and local culture in the archipelago is applied peacefully, which in the end this religion helps the followers to understand "reality", and manifests it into certain world view patterns (weltanschauung as in the form of socio-cultural institutions, and influences development around it (Azra, 1996) In the relation of Islam and the natural culture of Jambi, this religion permeates and influences the values and teachings of its adat seloko, and thus also influences the life and development of its people. This pattern of Islamic and cultural relations does not mean without challenges. The relationship between the two is about how the viewpoint of the adherents of Islam when in contact with socio-cultural phenomena that in the end there is an interrelation (dialectics) that influence each other: Islam as a social reality can act as a subject that dynamics and determine historical development, and can also be an object due to pressure from the power of other social factors (Azra, 1996).

Islam which becomes the worldview of its adherents in the archipelago is related to the social phenomena around it, and in the end, there is a reciprocal connection (dialectic); Islam has a role as the determining and dynamizing subject of history, and vice versa is also an object due to external forces.

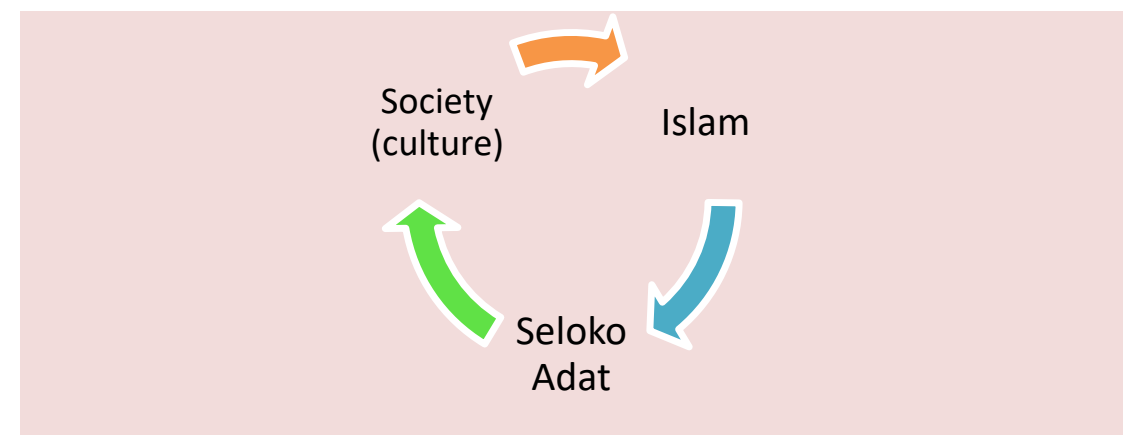

Picture 2 Dialectical Process 


\section{Relationship of Islam, Seloko Adat, and Society (Culture)}

The power of Islam in social struggle is very dependent on the ability developed by its adherents in facing the challenges of change. In the case of the relation between Islam and Jambi Malay culture, the dialectical process cannot be avoided. Borrowing Berger and Luckman's theory of "The Social Construction of Reality" (Berger, 1991), factually the (cultural) activities of the Jambi Malay community are influenced by Islamic values and teachings. Conversely, Islam that developed in Jambi is also influenced by the culture that developed in its community. Seloko adat is a representation of the dialectics (see diagram of the relationship between Islam and Jambi Seloko Malays in Picture 2).

\section{CONCLUSION}

Da'wah based on the local wisdom of the oral tradition of seloko adat of Jambi is part of an ongoing process of relations. Some of these relationships are constructed in the culture of the Jambi Malay community in which they borrow the theory of J. J. Hoenigman, manifested in the form of ideas, activities, and artifacts. The ideal form of its culture is abstract and exists in the minds of its people. If the idea is poured into written form, then the locus of ideas is in these texts. Furthermore activities are actions that are patterned in the form of social systems that are built, are concrete/real in daily life and documented. The cultural form of the Malay people of Jambi is none other than the manifestation of the creativity of the people in understanding the Islamic values associated with local culture. This relationship forms a new culture that is different from previous cultures, and people's lives are organized according to what they have created.

\section{BIBLIOGRAPHY}

Abdullah, A. A. (2006). Pendekatan Islam Hadhari dan Pemerkasaan Hubungan Etnik. Retrieved from www.upm.edu.my.

Al Munir, M. I, \& Ja'far, M. H. (2013). Etika Kepemimpinan dalam Seloko Adat Melayu Jambi. Kontekstualita: Jurnal Penelitian Sosial Keagamaan 28(2), $127-$ 140.

Aliyas (2013). Meninjau Kembali Sejarah Masuknya Islam di Jambi. Media Akademika. 28(3), 301-318.

Arafah, N. (2002). Pengetahuan Lokal Suku Moronene Dalam Sistem Pertanian Di Sulawesi Tenggara. Bogor. Program Pascasarjana Institut Pertanian Bogor.

Armansyah, Y. (2017) Kontribusi Seloko Adat Jambi dalam Penguatan

Demokrasi Lokal, Sosial Budaya 14(1) 1-13. DOI:10.24014/sb.v14i1.4158

Ayatroehadi (1986). Kepribadian Budaya Bangsa. Jakarta: Pustaka Jaya.

Azra, A. (1996). Pergolakan Politik Islam, Dari Fundamentalisme, Modernisme Hingga

Post-Modernisme. Jakarta: Penerbit Paramadina. 
Berger, P. L., \& Luckmann, T.(1991). The Social Construction of Reality: A Treatise in the Sociology of Knowledge, Penguin Books

Budiono, H. (2002). Simbolisme Dalam Budaya Jawa. Yogyakarta, Hanindita.

Gafar, A. (2012). Peranan Seloko Dalam Adat Perkawinan Kota Jambi, Pena, 2(3) 43-62. Retrieved from https://onlinejournal.unja.ac.id/pena/article/view/1441

Gibb, H. A. R. (1962). Studies on The Civilization of Islam. USA: Beacon Press.

Ibtihaj, M. (2006). Islam Jawa, Kajian Fenomenal Tentang Pengarub Islam dalam Budaya Jawa. Yogyakarta: Tugu Publisher.

Keraf, S. (2006). Etika Lingkungan. Jakarta: Kompas.

Koentjaraningrat. (1976). Manusia dan Kebudayaan di Indonesia. Jakarta: Djamban.

Koentjaraningrat. (1980). Manusia dan Kebudayaan di Indonesia. Jakarta: Djambatan.

Koentjaraningrat. (1990). Pengantar Ilmu Antropologi I. Jakarta: UI Press.

Kuntowijoyo (1993). Muslim Kelas Menengah Indonesia 1910-1950, Bandung: Mizan.

Lembaga Adat Propinsi Jambi (1993). Buku Pedoman Adat Jambi. Jambi:

Pemerintah Daerah Tingkat I Jambi

Masroer, Ch. Jb. (2004). The History Of Java, Sejarah Perjumpaan Agama-Agama di Jawa. Yogyakarta: Ar-Ruzz.

Mitchell, B., Setiawan, B. \& Rahmi, D. H. (2000). Pengelolaan Sumberdaya dan Lingkungan. Gajah Mada University Press: Yogyakarta.

Mustafid. (2009). Kampung Kuta; Dusun Adat Yang Tersisa Di Ciamis. Retrieved from http:/ / artikelindonesia.com/kampung-kuta-dusun-adat-yang-tersisadi-ciamis.html.

Muzakir, A. (2010). Perspektif Baru tentang Tiga Belas Abad Islam di Jambi” Innovatio, 9(1). $\quad$ Retrieved from http://ejournal.iainjambi.ac.id/index.php/Innovatio/article/download/514/478.

Noor, J. T. (2016). Seloko Sebagai Memori Kolektif Tradisi Tutur Bijak Masyarakat Melayu Jambi. Slide Show unpublished.

Noor, Sihabudin. (1997). Artikulasi Politik Islam: Studi tentang PPP 1972-2004. Jakarta: SPS UIN Jakarta.

Nurhasanah (2004). Makna Simbolik Seloko Adat Jambi, Magister Thesis. Depok: Program Pascasarjana Fakultas Ilmu Pengetahuan Budaya Universitas Indonesia.

Nurhasanah (2013). Ekspresi Simbolik Seloko Adat Jambi. Media Akademika, 28(1) retrieved from http://ejournal.iainjambi.ac.id/index.php/mediaakademika/article/view/171.

Putra, B. A. (2018). Islamisasi di Dunia Melayu Jambi. Titian: Jurnal Ilmu Humaniora, 2(1), 29 - 50. DOI:10.22437/titian.v2i1.5214

Radmilla, S. (2011). Kearifan lokal : Benteng Kerukunan. Jakarta: Gading Inti Prima.

Rahima, A. (2013). Seloko Adat pada Masyarakat Melayu Jambi Tinjauan Struktural, Jurnal Ilmiah Universitas Batanghari Jambi. 13(1). 
Rahyono, F. X. (2009). Kearifan Budaya dalam Kata. Jakarta: Wedatama Widya Sastra.

Ridwan, N. A. (2007). Landasan Keilmuan Kearifan Lokal. Jurnal Studi Islam dan Budaya, 5(1), 27-38.

Rosidi, A. (2011). Kearifan Lokal dalam Perspektif Budaya Sunda. Bandung. Kiblat.

Sartini. (2004). Menggali Kearifan Lokal Nusantara Sebuah Kajian Filsafat. Jurnal Filsafat. $\quad 37(2) \quad 111-120 . \quad$ Retrieved from https://jurnal.ugm.ac.id/wisdom/article/view/33910

Suyatno, S. Revitalisasi Kearifan Lokal sebagai Upaya Penguatan Identitas Keindonesiaan. Retrieved from http://badanbahasa.kemdikbud.go.id/lamanbahasa/artikel/1366

Syam, K. (ed). (2001). Pokok-pokok Adat Pucuk Jambi Sembilan Lurah Jilid III Sastra Adat Jambi. Jambi. Lembaga Adat Provinsi Jambi.

Syam, K. (ed). (2001). Pokok-pokok Adat Pucuk Jambi Sembilan Lurab Jilid IV Tata Upacara Adat Jambi. Jambi. Lembaga Adat Provinsi Jambi.

Tiezzi, E. N. Marchettini, \& M. Rossini. (2003). Extending the Environmental Wisdom beyond the Local Scenario: Ecodynamic Analysis and the Learning Community. Retrieved from http://library.witpress.com/pages/paperinfo.asp.

Ulum, B. (2013). Politik Hukum Islam Melayu Jambi Adat Besendi Syarak, Syarak Besendi Kitabullah dan Hubungannya dengan Upaya Kontekstualisasi Hukum Islam di Jambi. Media Akademika. 28(1).

Wahono, F. (2005). Pangan, Kearifan Lokal dan Keanekaragaman Hayati. Yogyakarta: Cindelaras Pustaka Rakyat Cerdas.

Wennyta (2015). Politeness Use in Seloko Custom Wedding Ceremony 'Ulur Antar Serah Terima Pengantin'in the Book Jambinese Traditional Ceremony 4th Volume. International Journal of Language Learning and Applied Linguistics World (IJLLALW), 8(3).

Wirawan, S. S. (1992). Psikologi Lingkungan. Jakarta: Grasindo.

Yatim, B. (2007). Sejarah Peradaban Islam. Jakarta. Raja Grafindo Persada. 